Edyta Żyrek-Horodyska

Uniwersytet Jagielloński

edytazyrek@wp.pl

\title{
Od amerykańskiego snu Thompsona po ukraiński Mordor Szczerka. Estetyzacja świata w duchu gonzo
}

\author{
From Thomson's American Dream to Szczerek's Ukrainian Mordor. Aestheticization \\ of the World in Gonzo Style
}

\begin{abstract}
The article is an attempt at a comparative analysis of two journalistic texts written in the tradition of New Journalism and classified today as instances of the gonzo style. Two books are analysed: Fear and Loathing in Las Vegas by Hunter S. Thomson (1971) and Przyjdzie Mordor i nas zje, czyli tajna historia Stowian [Mordor Will Come and Eat Us: A Secret History of the Slavs] by Ziemowit Szczerek (2013). The article aims at showing that journalistic texts following the gonzo aesthetics mime the narrative strategies found in literature (with special emphasis on thriller and picaresque novel), but also often openly question their assumptions.
\end{abstract}

Keywords: literary journalism, gonzo, Hunter S. Thompson, Ziemowit Szczerek, aesthetics, picaresque novel

Streszczenie: Artykuł jest próbą komparatystycznego spojrzenia na dwa teksty reportażowe wpisujące się w tradycję Nowego Dziennikarstwa i klasyfikowane dziś jako przykłady stylu gonzo. Analizom poddane zostają książki: Lęk i odraza w Las Vegas Huntera S. Thompsona z 1971 roku oraz Przyjdzie Mordor i nas zje, czyli tajna historia Stowian autorstwa Ziemowita Szczerka z 2013 roku. Szkic ten ma na celu pokazanie, że reportaże będące realizacją estetyki gonzo naśladują strategie narracyjne zaczerpnięte z literatury (ze szczególnym wskazaniem na powieść sensacyjną czy powieść drogi), a także wielokrotnie w sposób otwarty dyskutują z ich założeniami.

Słowa kluczowe: reportaż literacki, gonzo, Hunter S. Thompson, Ziemowit Szczerek, estetyka, powieść drogi 
Refleksja naukowa nad reportażem oraz jego granicami koncentruje się dziś między innymi wokół zagadnienia hybrydyczności gatunku, który z jednej strony otwiera się na literaturę, z drugiej zaś silnie akcentuje swą odrębność od form fikcjonalnych. Poszukując rozwiązań nowatorskich, by nie rzec eksperymentalnych, reportażyści często odchodzą od tradycyjnych założeń teorii reportażu ${ }^{1}$, które nie zawsze w sposób adekwatny przystają do opisu płynnej nowoczesności ${ }^{2}$. Jedną z konsekwencji utraty wiary w klasyczne, obiektywne media, fundowane na przeświadczeniu o transparencji języka przekazów prasowych, jest kształtowanie się rozmaitych form pogranicznych. Wśród nich szczególnym zainteresowaniem cieszy się tzw. gonzo journalism, którego rozwój odczytywać można jako odpowiedź na zmieniające się potrzeby odbiorcy mediów, ale i przemiany samych środków masowego przekazu.

Niniejszy szkic jest próbą komparatystycznego odczytania dwóch tekstów wpisujących się w bogatą tradycję Nowego Dziennikarstwa, podającego w wątpliwość zarówno pakt referencjalny zawierany między twórcą a odbiorcą, jak również kilka pomniejszych założeń, na których opiera się klasyczne dziennikarstwo prasowe ${ }^{3}$. Przedmiotem mojej analizy czynię książkę Lęk $i$ odraza $w$ Las Vegas ${ }^{4}$ Huntera S. Thompsona z 1971 roku, uznawaną za jedno z pierwszych dzieł utrzymanych w duchu gonzo, oraz utwór Przyjdzie Mordor i nas zje, czyli tajna historia Stowian ${ }^{5}$ autorstwa Ziemowita Szczerka z roku 2013. Bezpośrednią inspiracją do podjęcia badań porównawczych nad tymi tekstami były liczne uwagi formułowane przez polskiego dziennikarza, który w swej pracy wielokrotnie powoływał się na koncepcje amerykańskiego twórcy. Warto zatem zastanowić się, jak daleko w pracach autora Przyjdzie Mordor... sięgają Thompsonowskie inspiracje, oraz scharakteryzować w tym kontekście przemiany, jakim gonzo podlegało w ciągu kilkudziesięciu lat. Szczególnej uwagi domaga się zwłaszcza dostrzegalny w pracach obu twórców zabieg estetyzowania opisywanej rzeczywistości, za sprawą którego w tekstach dziennikarskich wyraźnie widoczne na poziomie stylistycznym i treściowym stają się nawiązania do literatury, ze wskazaniem zwłaszcza na powieść drogi.

${ }^{1}$ Por. K. Wolny-Zmorzyński, Reportaż-jak go napisać, Warszawa 2004.

2 O wpływie myśli ponowoczesnej na współczesny reportaż pisze Mateusz Zimnoch; por. tenże, Reportaż w ptynnej nowoczesności, „Znak” 2012, nr 3, s. 116-118.

3 Wśród wyznaczników prasowości Kazimierz Wolny-Zmorzyński i Andrzej Kaliszewski wymieniają między innymi: szczegółowość, zwięzłość, dominację funkcji informacyjnej tekstu, tożsamość osoby mówiącej z autorem, asertoryczny charakter wygłaszanych prawd, przeświadczenie, iż prezentowane osoby i wydarzenia odnoszą się wprost do rzeczywistości; por. K. Wolny-Zmorzyński, A. Kaliszewski, W. Furman, Gatunki dziennikarskie. Teoria, praktyka, język, Warszawa 2006, s. 18-19.

${ }^{4}$ Por. H.S. Thompson, Lęk i odraza w Las Vegas, tłum. M. Wróbel, M. Potulny, b.m. 2013.

5 Por. Z. Szczerek, Przyjdzie Mordor i nas zje, czyli tajna historia Stowian, Kraków 2013. 


\section{Nowe Dziennikarstwo a dziennikarstwo gonzo}

Choć współcześnie rozwój Nowego Dziennikarstwa stanowi jeden z ważniejszych obszarów badań medioznawczych, pojęcie to wciąż nie doczekało się spójnej, wyczerpującej definicji. Problematyczna okazuje się zwłaszcza polisemiczność tego terminu. Jego polskie rozumienie, kształtujące się pod wpływem humanistycznej refleksji Ryszarda Kapuścińskiego ${ }^{6}$, znacząco różni się od ujęcia amerykańskiego, w którym New Journalism koncentruje się wokół trzech podstawowych założeń: estetyzacji świata przedstawionego, subiektywizacji wypowiedzi oraz eksperymentowania $\mathrm{z}$ tradycyjnymi formami dziennikarskimi.

Nowe Dziennikarstwo narodziło się w Stanach Zjednoczonych w latach sześćdziesiątych i siedemdziesiątych XX stulecia z potrzeby zrewidowania tradycyjnych funkcji mediów. Zapowiedzi jego powstania szukać należy jednak już w ostatnich latach XIX stulecia. Wówczas amerykański dziennikarz i wydawca Joseph Pulitzer wypracował koncepcję tak zwanego żółtego dziennikarstwa (ang. yellow journalism), którego zwolennicy, chcąc zaakcentować jego odmienność od wcześniejszych standardów redagowania prasy, zaczęli określać je jako new journalism ${ }^{8}$. Przekaz żółtej prasy ${ }^{9}$ kierowany był do mas, zainteresowanych plotkami i serwowaną $\mathrm{w}$ wysoce emocjonalnym tonie tematyką sensacyjną. Za twórcę i głównego teoretyka Nowego Dziennikarstwa w XX wieku uznaje się Toma Wolfe’a, który w 1963 roku na szpaltach „Esquire" opublikowat tekst zatytułowany There Goes (Varoom! Varoom!) That Kandy-Kolored (Thphhhhhh!) Tangerine-Flake Streamline Baby (Rahghhh!) Around the Bend (Brummmm ... Around the Bend (Brummmmmmmmmmmmmm), będący - wymykającą się jakimkolwiek genologicznym ustaleniom - dziennikarską relacją z wystawy samochodów. Autor doszedł do wniosku, iż wydarzenia niecodzienne wymagają od niego użycia niesztampowego języka ${ }^{10}$. W wydanej w 1973 roku książce The New Journalism Wolfe wyłożył główne założenia nowego kierunku. Jak pisze Jessie Swigger, w ustaleniach Amerykanina Nowe Dziennikarstwo jawi się jako

a new literary form combining traditional reporting with novelistic devices such as telling stories using scenes rather than a chronological narrative; including

6 Por. R. Kapuściński, Nowe dziennikarstwo, „Akcent” 2012, nr 3, s. 8.

7 Por. R. Boynton, The New New Journalism: Conversations with America's Best Nonfiction Writers on Their Craft, New York 2005, s. XI.

${ }^{8}$ J.D. Keeler, W. Brown, D. Tarpley, Ethics [w:] American Journalism: History, Principles, Practices, red. W.D. Sloan, L. Mullikin Parcell, Jefferson, North Carolina-London 2002, s. 48.

${ }^{9}$ Nazwa wywodzi się od żółtej farby, którą wykorzystywano w prasie końca XIX wieku w Stanach Zjednoczonych w celu pozyskania uwagi odbiorcy.

${ }^{10}$ Por. P. Gorner, Tom Wolfe: In Big League as a Writer [w:] Conversations with Tom Wolfe, red. D. McInnis Scura, Mississippi 1990, s. 99. 
conversational speech or full dialogue; adopting a personal point of view; and recording the details of everyday life ${ }^{11}$.

Założenia te bardzo szybko znalazły szerokie grono naśladowców. Wśród nich znaleźli się Truman Capote, Joan Didion, Norman Mailer oraz liczni publicyści związani z magazynem „Rolling Stone”, których krytykowano za wprowadzanie elementów fikcjonalnych do tekstów prasowych, jak również za szczególne uprzywilejowanie w tekście osoby dziennikarza. Traktowanie reportera jak artysty słowa ${ }^{12}$ wzbudzało kontrowersje zwłaszcza wśród autorów przywiązanych do tradycyjnego dziennikarstwa informacyjnego.

Wkład Thompsona w rozwój Nowego Dziennikarstwa opiera się na założeniu, iż reporter nie tylko opowiada o zdarzeniach, lecz także aktywnie w nich uczestniczy. Przeświadczenie to stoi u podstaw rozwijającego się od lat sześćdziesiątych dziennikarstwa gonzo. Choć początkowo forma ta traktowana była jak dziennikarska awangarda, współcześnie na gruncie poetyki sformułowanej pojawiają się już szczegółowe wytyczne, pozwalające określić, czy dany tekst mieści się $\mathrm{w}$ analizowanym nurcie. Wśród cech koniecznych i wystarczających znalazły się: eksponowanie autorskiego ,ja” połączone z subiektywizacją wypowiedzi, podważenie założeń klasycznego dziennikarstwa opierającego się na skonwencjonalizowanych formatach i gatunkach, wykorzystywanie kolokwialnego języka niepoddającego się rygorom poprawności politycznej, jak również wchodzenie przez autora w trakcie dziennikarskiej podróży w odmienne stany świadomości za sprawą najróżniejszych używek ${ }^{13}$.

Jak zauważa Bartosz Stopel, gonzo nie cieszyło się początkowo w Polsce dużą popularnością, wyjąwszy nieliczne opracowania poświęcone książce Thompsona ${ }^{14}$. Uwagę zwrócono na ów nurt pod koniec lat dziewięćdziesiątych wraz z pojawieniem się ekranizacji Lęku $i$ odrazy... Wzmożona refleksja naukowa towarzyszyła jednak dopiero publikacji książki Szczerka (określanej jako „łże-reportaż”'15), która nawiązywała do amerykańskiego wzorca, a nawet twórczo go reinterpretowała.

Refleksja nad głównymi założeniami Nowego Dziennikarstwa w Polsce zakorzeniona jest w myśli Kapuścińskiego, który w swej definicji w odmiennym miejscu niż Amerykanie stawia punkt ciężkości: „Nowe Dziennikarstwo

${ }^{11}$ J. Swigger, New Journalism [w:] Culture Wars: An Encyclopedia of Issues, Viewpoints, and Voices, red. R. Chapman, Armonk, NY 2010, s. 398.

12 Por. The Reporter as Artist: A Look at the New Journalism Controversy, red. R. Weber, New York 1974.

${ }^{13}$ K. Puto, A. Małecka, J. Bińczycki, Wstęp, „Ha!art” 2013, nr 1 (41), s. 1-2.

14 Por. J. Drozdowicz, Lęk i odraza. O popkulturowej obecności Huntera S. Thompsona [w:] Kultura popularna w spoteczeństwie wspótczesnym. Teoria i rzeczywistość, red. J. Drozdowicz, M. Bernasiewicz, Kraków 2010, s. 191-198.

15 Por. I. Adamczewska, Wariacje na temat pewnego paktu. O dziennikarstwie gonzo, „Łódzkie Studia Literaturoznawcze" 2014, nr 3 (1), s. 190. 
reprezentuje nowe wartości i posiada szczególną wagę, gdyż jest to gatunek, który informuje, ale też objaśnia, zmusza do refleksji”' ${ }^{16}$. Nowe Dziennikarstwo w ujęciu autora Cesarza miało zrewidować dotychczasowe zadania mediów: ich funkcją nie powinno być wyłącznie informowanie o wydarzeniach, lecz także wzbudzenie w odbiorcy namysłu nad nimi. Stąd konieczność eseizacji przekazów medialnych, wymagającej od pracowników mediów oraz ich odbiorców krytycznego myślenia. Beata Nowacka dostrzega, że z założenia tego wynika postulat poszerzenia granic reportażu ${ }^{17}$ o elementy tradycyjnie zarezerwowane dla literatury. O ile jednak w amerykańskim New Journalism literackość sprowadza się do wykorzystywania technik właściwych dla form fikcjonalnych, o tyle u Kapuścińskiego oznacza coś zgoła innego: „uniwersalne przesłanie, ponadczasowość i wielość interpretacji”18.

\section{Gonzo journalism: perspektywy oglądu}

W ostatnich latach wśród polskich badaczy zauważyć można wzrastające zainteresowanie gonzo, czego dowodem jest chociażby artykuł Zbigniewa Bauera Dziennikarstwo "gonzo": epizod czy staty trend $w$ dziennikarstwie ${ }^{19}$, opublikowany na kilka lat przed powstaniem słynnego „łże-reportażu” Szczerka. Medioznawca podkreśla, iż twórczość autorów naśladujących styl Thompsona cechują „skrajny subiektywizm, nieukrywanie osobistych ocen, posuniętych do insynuacji i osobistych ataków, epatowanie wulgaryzmami, szyderstwami, drwiną" ${ }^{20}$. Podążając za ustaleniami Johna Ryle'a ${ }^{21}$, badacz skupia się na omówieniu związków Kapuścińskiego z analizowanym nurtem. Uwagi te pozwalają w nowym świetle spojrzeć na zarzuty stawiane reporterowi przez Artura Domosławskiego w głośnej książce Kapuściński non-fiction. Sam Kapuściński - co warto podkreślić - do gonzo odnosił się w sposób zachowawczy, a nawet krytyczny. W IV części Lapidariów nurt ten powiązał z „uczestniczeniem w zdarzeniach hedonistycznych, skandalach", oraz z przyjmowaniem przez dziennikarza postawy „lekceważenia, arogancji, ośmieszania autorytetów”22.

${ }^{16}$ R. Kapuściński, Nowe..., dz. cyt., s. 8.

17 B. Nowacka, Magiczne dziennikarstwo. Ryszard Kapuściński w oczach krytyków, Katowice 2004, s. 22.

18 Tamże.

19 Por. Z. Bauer, Dziennikarstwo "gonzo": epizod czy trwaty trend w dziennikarstwie? [w:] Dziennikarstwo a literatura w XX i XXI wieku, red. K. Wolny-Zmorzyński, W. Furman, J. Snopek, Warszawa 2011.

20 Por. tamże, s. 87.

${ }^{21}$ Badacz zwracał uwagę, że opis afrykańskiego orientalizmu ma u Kapuścińskiego cechy gonzo.

${ }^{22}$ R. Kapuściński, Lapidaria IV-VI, Warszawa 2008, s. 84-85. 
W opublikowanych na łamach „Zagadnień Rodzajów Literackich” $M a-$ teriatach do "Stownika rodzajów literackich" pod hasłem gonzo journalism ${ }^{23}$ odnajdziemy informacje dotyczące zarówno genezy terminu, jak i krótkie omówienie najważniejszych polsko- i anglojęzycznych tekstów utrzymanych $\mathrm{w}$ tym duchu. Istotne ustalenia na ten temat przynosi ponadto artykuł Izabelli Adamczewskiej zatytułowany Wariacje na temat pewnego paktu: o dziennikarstwie gonzo, gdzie twórczość Jacka Hugo-Badera przeanalizowana zostaje w kontekście głównych idei przyświecających pisarstwu Thompsona. Cennym uzupełnieniem dla wspomnianego szkicu jest praca Katarzyny Frukacz: Amerykańskie Nowe Dziennikarstwo po polsku? Transfer poetyk, problemy adaptacyjne ${ }^{24}$. Badaczka potwierdza w niej tezę Adamczewskiej dotyczącą możliwości włączenia twórczości autora Białej goracczki do badanego nurtu, analizując ponadto rozmaite interferencje między założeniami Nowego Dziennikarstwa a pracami Mariusza Szczygła czy Wojciecha Jagielskiego.

Gonzo poświęcony został numer czasopisma „Ha!art”25, gromadzący wypowiedzi zarówno teoretyków, jak i praktyków związanych z popularyzowaniem tej formy. We wstępie do periodyku redaktorzy stawiają interesującą hipotezę, iż gonzo jest związane nie tylko z dziennikarstwem, lecz także z literaturą:

Gonzo, mówiąc w skrócie, jest stylem subiektywnego zapisu realnych wydarzeń, balansowaniem na granicy relacji faktograficznej oraz osobistej impresji. (...) Powstało po to, by zagrać na nosie koncernom medialnym i zniszczyć grzeczne dziennikarstwo ${ }^{26}$.

Jako swoisty prototyp tej formy wskazane zostają dygresyjne sylwy szlacheckie oraz Pamiętniki Jana Chryzostoma Paska. Warto dodać, iż obok tekstów przynoszących interpretacje i analizy badanego zjawiska w numerze pojawiają się tłumaczenia tekstów takich autorów, jak Oscar Zeta Acosta, Lester Bangs czy Helge Timmerberg.

Obszerne uwagi dotyczące gonzo sformułowane zostały na gruncie anglosaskim. Badacze wiele miejsca poświęcają zwłaszcza twórczości Thompsona oraz późniejszych jego naśladowców, których teksty stały się punktem wyjścia do refleksji nad referencjalnym wymiarem funkcjonowania mediów. John C. Hartsock w książce traktującej o dziennikarstwie literackim (ang. literary journalism) dostrzega pograniczny charakter analizowanej formy, która

${ }^{23}$ Por. I. Adamczewska, Gonzo journalism, „Zagadnienia Rodzajów Literackich” 2014, z. 1, s. 341-343.

${ }^{24}$ Por. K. Frukacz, Amerykańskie Nowe Dziennikarstwo po polsku? Transfer poetyk, problemy adaptacyjne, „Biblioteka Postscriptum Polonistycznego” 2015, nr 5, s. 49-61.

25 Por. „Ha!art” 2013, nr 1 (41).

26 Tamże, s. 1. 
oscyluje między językiem mediów a językiem artystycznym ${ }^{27}$. Obszerny komentarz na ten temat znajdujemy ponadto w książce Key Concepts in Journalism Studies, gdzie gonzo określone zostaje jako „styl dziennikarski”, charakteryzujący się hiperbolizowaniem rzeczywistości oraz usytuowaniem autora w centrum przedstawianej historii ${ }^{28}$. Autorzy książki Keywords in News and Journalism Studies zauważają, że teksty pisane w tym duchu powielają w dużej mierze podobny schemat narracyjny, na który składają się: opowiadanie historii w pierwszej osobie oraz wplatanie w tok wypowiedzi rozmaitych dialogów, transkrypcji czy niedokończonych notatek któregoś z podróżników ${ }^{29}$.

\section{Gonzo a medialna estetyzacja rzeczywistości}

Popularność gonzo wiąże się z coraz szerszym oddziaływaniem mediów na kształtowanie się szczególnego typu odbiorcy określanego jako homo aestheticus. Człowiek estetyczny, jak pisze Agata Bielik-Robson, jest „prawdziwym mieszkańcem nowoczesności, którą rządzi zasada, że "wszystko, co stałe, wyparowuje " 30 . Wydaje się, iż Nowe Dziennikarstwo to nurt, który twórczo reinterpretuje konwencję medialnej estetyzacji rzeczywistości. Faktem jest, iż już dwudziestowieczny reportaż literacki spod znaku Egona Erwina Kischa czy Melchiora Wańkowicza znacząco przyczynił się do rozwoju tej tendencji. Autor Tworzywa zasłynął niezwykle liberalnym podejściem do fikcji. W imię koherencji dyskursu posuwał się nawet do tworzenia jednego bohatera tekstu z kilku rzeczywiście istniejących postaci, tłumacząc to lakonicznym stwierdzeniem: „Nie ma takich ludzi, którym tyle by się zdarzyło, ile ja potrzebuję”31.

Zdaniem Wolfganga Welscha estetyzacja wiąże się z tym, iż „tradycyjne cechy sztuki przenosi się na rzeczywistość, codzienności nadaje się artystyczny charakter"32. Ważną rolę w tym procesie odgrywają media, które za pomocą silnie oddziałujących obrazów przedstawiają świat w sposób skonwencjonalizowany. Zgodnie z ustaleniami Mike’a Featherstone’a współcześnie „sztuka przestaje być osobną, wydzieloną rzeczywistością; przenika procesy produkcji i reprodukcji, dzięki czemu wszystko, nawet codzienne i banalne życie, nabiera

27 Por. J.C. Hartsock, A History of American Literary Journalism: The Emergence of a Modern Narrative Form, Massachusetts 2000, s. 200.

28 B. Franklin, Gonzo Journalism [w:] Key Concepts in Journalism Studies, red. B. Franklin, M. Hamer, M. Hanna, Trowbridge, Wiltshire 2005, s. 95.

${ }^{29}$ B. Zelizer, S. Allan, Keywords in News and Journalism Studies, Glasgow 2010, s. 51.

30 A. Bielik-Robson, Inna nowoczesność. Pytania o wspótczesna formute duchowości, Kraków 2000, s. 19.

${ }^{31}$ K. Kąkolewski, Wańkowicz krzepi, Lublin 1984, s. 18.

${ }^{32}$ W. Welsch, Procesy estetyzacji. Zjawiska, rozróżnienia, perspektywy, tłum. J. Gilewicz [w:] Sztuka i estetyzacja, red. K. Zamiara, M. Golka, Poznań 1999, s. 13. 
znamion sztuki i staje się estetyczne"33. Nurt gonzo, sprzeciwiający się schematycznemu podejściu do tekstu dziennikarskiego, chciał widzieć w reportażyście osobę dzielącą się z czytelnikiem własnymi przeżyciami. Zastanawiająca wydać może się natomiast ich nadmierna multiplikacja, która z punktu widzenia odbiorcy przesuwa jego doświadczenia z domeny estetyki w kierunku dopełniającej ją anestetyki. Efekt anestetyczny sprowadzał Welsch do prostego założenia: „im więcej estetyki, tym więcej anestetyki” ${ }^{34}$. Nagromadzenie estetyzujących przekazów, komunikatów oddziałujących na sferę emocjonalną wywołuje u odbiorcy - zdaniem badacza - stopniowe zobojętnienie. Anestetyka odnosi się zatem do „bardzo różnych rodzajów niewrażliwości, znieczulenia społecznego i znieczulenia na różnicę między oryginałem a symulacją̧35.

Rozmaite zabiegi służące estetyzacji opisywanej rzeczywistości wyraźnie dostrzegalne są na kartach książki Thompsona. Bogata w najrozmaitsze doświadczenia podróż dziennikarza motywowana jest przede wszystkim chęcią rozprawienia się z ideą ,amerykańskiego snu”. Główni bohaterowie Lęku i odrazy... przyjeżdżają do Las Vegas w poszukiwaniu ideałów, o których pisali ówcześni pisarze i regularnie donosiły media. Rzeczywistość okazuje się jednak zdecydowanie mniej atrakcyjna od literackiego wzorca. Dostęp do niego zapewniają dziennikarzowi i jego kompanowi wyłącznie zażywane w dużych ilościach środki odurzające, oferujące podróżnym poczucie nieskrępowanej wolności:

Wspaniałe, wszechogarniające uczucie, że cokolwiek robimy, jest dobre; że to my wygrywamy. Myślę, że to jest najważniejsze - wrażenie nieuchronnego zwycięstwa nad siłami wszystkiego, co stare i złe. Nie w militarnym sensie; nie o to nam chodzi. Nasza energia po prostu dominuje ${ }^{36}$.

Ameryka widziana oczyma odurzonego dziennikarza jest krajem otwartych granic i wielkich możliwości. Podziwiana zza szyby wypożyczonego kabrioletu jawi się jako kraj uśmiechniętych, gościnnych ludzi, swobodnych rozmów i nieskrępowanej niczym zabawy. Gdy jednak odurzenie narkotyczne czy alkoholowe mija, pojawia się pytanie o skutki ciągłego życia w stanie poszerzonej świadomości. Opisywana przez Thompsona rzeczywistość zbliża się do powieściowej wyłącznie w sferze onirycznych doznań. „Amerykański sen” przedstawiony zostaje jako wykreowane przez media marzenie, ułuda sprzedawana odbiorcom w kolejnych numerach najpoczytniejszych magazynów.

${ }_{33}$ M. Featherstone, Postmodernizm i estetyzacja życia codziennego, tłum. P. Czapliński, J. Lang [w:] Postmodernizm. Antologia przektadów, red. R. Nycz, Kraków 1998 s. 308.

${ }_{34}$ W. Welsch, Estetyka i anestetyka, tłum. M. Łukasiewicz [w:] Postmodernizm..., dz. cyt., s. 527.

35 Tamże, s. 534.

${ }^{36}$ H.S. Thompson, dz. cyt., s. 86. 
Podobnie jak Thompson, Szczerek także opisuje świat oglądany pod wpływem rozmaitych używek. Na Ukrainę spogląda odurzony dużymi ilościami balsamu Wigor oraz alkoholu. „Im więcej piłem, tym bardziej podobało mi się tutaj”37 - deklaruje dziennikarz, który tak wspomina swą podróż za wschodnią granicę: „I wyglądało to wszystko tak, jakbym wjechał na teren historii alternatywnej własnego kraju"38. Ukrainę Szczerka tworzą dwa obrazy. Pierwszy z nich zakorzeniony jest $\mathrm{w}$ przeświadczeniu o egzotyce tego kraju, który - choć podobny do Polski - przez turystów przyjeżdżających do Lwowa oceniany jest jako gorsza i brzydsza wersja własnej ojczyzny. Ukraina to kwintesencja tego, co wschodnie; tego, na co trudno spojrzeć bez uruchomiania lawiny najróżniejszych stereotypów narodowych. Powiada Szczerek: „Czasem docierało do mnie, że jeździliśmy tam oglądać po prostu nędzę i że to nie było fair, bo w ten sposób chcieliśmy sami poczuć się mniej nędzni”39. Drugi obraz Ukrainy wyłaniający się z książki Przyjdzie Mordor... ogniskuje się wokół niezwykłości oglądanych miejsc i ludzi, ocenianych przez współczesne media w kategoriach dobrze sprzedającego się produktu. Szczerek precyzyjnie wskazuje, za jakie relacje i zdjęcia z Ukrainy chcą płacić polscy odbiorcy. Doskonale obrazuje to historia grupy fotografów organizujących w Krakowie wystawy swych prac:

Gięli się przed babuszkami i przez filtry łapali refleksy światła na ich złotych zębach. Fotografowali wybebeszone moskwicze, dzieciaki bawiące się w ruinach kamienic, psy bez zębów, łap, oczu, uszu i ogonów. (...) Słowem - robili to samo, co ja. Robili z Ukrainy burdel na kółkach. Tyle że się do tego nie przyznawali ${ }^{40}$.

Współczesne media sprzedają odbiorcy świadomie wykreowane wizerunki ubóstwa i cierpienia. Gonzo - zdaniem Szczerka - tego rodzaju obrazów może dostarczyć najwięcej. Staje się ono zatem formą gry zarówno z oczekiwaniami czytelników, jak i polityką prowadzoną przez środki masowego przekazu.

\section{Gonzo w ustaleniach Thompsona i Szczerka}

Analiza porównawcza Lęku i odrazy... oraz Przyjdzie Mordor... każe zwrócić szczególną uwagę na zawartą w obu tekstach refleksję autotematyczną, ogniskującą się wokół tworzonego tekstu oraz dziennikarstwa gonzo en général. Tę podwójną perspektywę, z której spogląda na rzeczywistość autor-dziennikarz, sygnalizowała Adamczewska:

\footnotetext{
37 Z. Szczerek, dz. cyt., s. 11.

38 Tamże, s. 10.

39 Tamże, s. 43.

40 Tamże, s. 122.
} 
Zapis researchu sprawia, że teksty gonzo nazywane są metadziennikarskimi. Uczestnictwo, a niekiedy wręcz wywoływanie zdarzeń rozmywa granicę pomiędzy podmiotem i przedmiotem narracji ${ }^{41}$.

Książka Thompsona ze względu na liczne komentarze autotematyczne daje się czytać z jednej strony jako teoretyczna wykładnia stylu gonzo, z drugiej zaś jako próba zrealizowania wskazanych przez autora teoretycznych założeń analizowanej formy. Kluczową rolę w Lęku i odrazie... odgrywa rozdział zatytułowany Piszemy reportaż.. Rzut oka na prasę wakcji. Syf i porażka..., w którym pojawia się refleksja nad wymaganiami stawianymi przed dziennikarzem przez redakcję i czytelników. Przeświadczenie dotyczące prestiżu wykonywanego zawodu Thompson konfrontuje z alkoholowymi doświadczeniami reportera:

Odwróciłem się. To było zbyt obrzydliwe. Byliśmy przecież - przede wszystkim elitą krajowych dziennikarzy sportowych. I zebraliśmy się tutaj, w Las Vegas, z bardzo ważnego powodu - by opisać czwarty doroczny rajd Mint 400... A kiedy na kimś ciąży taka odpowiedzialność, to nie można sobie pozwolić na wygłupy ${ }^{42}$.

Gdy wyścig rusza, reporterzy, wbrew deklaracjom, nie skupiają się jednak na jego relacjonowaniu: „- No, to mamy ich z głowy - zauważył któryś z dziennikarzy. - Nie wrócą wcześniej niż za godzinę. Wracajmy do baru" ${ }^{43}$. Thompson dokonuje krytycznej rewizji wszelkich obowiązujących zasad sztuki dziennikarskiej. Jego bohater nie tyle opisuje wydarzenia, ile je kreuje, będąc inicjatorem często niechlubnych, awanturniczych zajść. Wielokrotnie skarży się na niemoc twórczą, w której pokonaniu mają mu pomóc kolejne butelki alkoholu. „Zacząłem ostro chlać, ostro myśleć i ostro notować” ${ }^{44}$ - deklaruje Raoul Duke, przestawiany w książce jako doktor nauk dziennikarskich, próbujący stworzyć reportaż dokumentujący przebieg pustynnych wyścigów. Wydarzenie jest dla niego jednak - jak się zdaje - wyłącznie pretekstem do opowiedzenia własnej historii.

W ujęciu Thompsona gonzo jawi się jako odpowiedź na schematyczne, zdawkowe, tworzone często zza biurka teksty dziennikarskie. Autor w Odrazie $i$ lęku... przeciwstawia im reportaże pisane bez żadnej pierwotnej tezy, swobodne w swej formie i treści, emocjonalne i apriorycznie kwestionujące możliwość wiernego odzwierciedlenia faktów. W jego myśleniu o roli mediów dostrzegalne jest przedkładanie indywidualnego doświadczenia nad uogólniające sądy, nawet jeżeli miałoby się to odbywać za cenę podważenia tradycyjnych zasad etyki dziennikarskiej:

${ }^{41}$ I. Adamczewska, Wariacje..., dz. cyt., s. 188.

${ }^{42}$ H.S. Thompson, dz. cyt., s. 51.

43 Tamże, s. 52.

${ }^{44}$ Tamże, s. 56. 
Uznałem, że w takiej podróży najlepiej zrobić z siebie pajaca i pójść w kompletny odpał, z piskiem opon przelecieć przez pustynię i napisać artykuł. Nie można przecież tracić z oczu głównego celu. Tylko o czym ma być ten tekst? Nikt nie był łaskaw mnie oświecić. Będziemy musieli rozgryźć to na własną rękę. Wolna ręka. „Amerykański sen”. (...) No to jazda: styl gonzo w czystej postaci ${ }^{45}$.

Ironia autora skierowana jest przede wszystkim w stronę redakcji, które w pogoni za newsem zapominają o celu samego wyścigu. Zadaniem dziennikarza nie jest już opisanie wydarzenia, lecz wykreowanie go przez nadanie znaczenia faktom błahym i nieistotnym. W reultacie funkcja emotywna zdobywa przewagę nad funkcją informacyjną, a walor estetyczny opowieści dominuje nad poznawczym.

Podobnie jak Thompson polski autor także włącza do Przyjdzie Mordor... osobny rozdział, w którym odsłania przed czytelnikiem swój warsztat i proponuje własną definicję gonzo. W wielu miejscach pozostaje ona zbieżna z założeniami pojawiającymi się w pracach Thompsona:

No i tak się porobiło, że zawodowo zacząłem zajmować się ściemnianiem. Łganiem. (...) Wystarczyło, bym napisał kilka tekstów na temat Ukrainy utrzymanych w tonie gonzo - a już miałem zlecenia. Epatowałem w tych tekstach ukraińskim rozdupczeniem i rozwłóczeniem. Musiało być brudno, mocno, okrutnie. Taka jest istota gonzo. W gonzo jest gorzała, są szlugi, są dragi, są panienki. Są wulgaryzmy. Tak pisałem i było dobrze ${ }^{46}$.

Myśląc o gonzo jak o „łże-reportażu”, Szczerek akcentuje paradoksalny, oksymoroniczny charakter tej formy. Stosowana przez autora na szeroką skalę fikcjonalizacja przekazów dziennikarskich jest - jego zdaniem - odpowiedzią na oczekiwania redakcji, chcących publikować na swych łamach teksty dosadne i kontrowersyjne, zarówno pod względem poruszanej problematyki, jak i wykorzystywanego przez autora języka.

W Przyjdzie Mordor... Szczerek przywołuje pokolenie bitników, szczególną uwagę poświęcając jednak nie Thompsonowi, lecz Jackowi Kerouacowi. Prześledziwszy ich prace, dochodzi do wniosku, że podobnie jak amerykańscy twórcy lat sześćdziesiątych polscy autorzy dziś także rozwijają własną „literaturę drogi”. Podczas jej tworzenia kierują nimi jednak zgoła odmienne pobudki:

Braliśmy plecaki i jechaliśmy w drogę. Nie czytaliśmy Kerouaca, bo nie dało się tego czytać. Tyle tam było pulsujących w każdą stronę, skłębionych bebechów. No i też dlatego, że było nam trochę głupio, bo nam, w przeciwieństwie do Kerouaca, o nic nie chodziło. (...) Jeśli chlaliśmy, przepierdalaliśmy czas, braliśmy narkotyki,

45 Tamże, s. 22.

46 Z. Szczerek, dz. cyt., s. 99. 
szukaliśmy tanich wstrząsów i tandetnych emocji, to nie po to, by przeciwko czemukolwiek się zbuntować, nawet nie po to, by przeżyć coś nowego, bo to wszystko już było, było, było - tylko po to, by robić cokolwiek ${ }^{47}$.

W wypowiedzi Szczerka dostrzec można ponowoczesne rozczarowanie literaturą, która potrafi wyłącznie powielać ukonstytuowane już wzorce i wykorzystywać wcześniejsze schematy. Podczas gdy teksty bitników miały być rodzajem polemiki z tradycyjnym dziennikarstwem, dzisiejsze gonzo nie rości sobie już praw do zmiany świata, nie ma ambicji, by stać się głosem jakiegokolwiek pokolenia. Aż trzykrotne podkreślenie przez autora faktu, że w dziennikarstwie i literaturze wszystko już było, pozwala włączyć książkę Szczerka w krąg odczytań ponowoczesnych, gdzie oprócz wyczerpującej swe twórcze możliwości literatury pojawia się reportaż hybrydyczny, zacierający granice między prawdą a fikcją.

\section{Dziennikarz - autor - narrator}

W świetle klasycznych teorii reportażu jednym z najważniejszych wyznaczników gatunku, odróżniającym go od form literackich, jest tożsamość autora zewnętrznego $\mathrm{z}$,ja” tekstowym. Zasada ta, przez wiele lat uznawana za dogmatyczną, współcześnie coraz częściej bywa podawana w wątpliwość, by wspomnieć tylko słynny tekst Wojciecha Tochmana W'sciekty pies ${ }^{48}$. Książki Thompsona i Szczerka również - co warto podkreślić - podejmują swoistą grę z przywołanym założeniem. Obaj dziennikarze informują jednak o tym czytelnika w zgoła odmienny sposób. Głównych bohaterów Lęku i odrazy... oraz Przyjdzie Mordor... łączy wiele: obaj pracują jako reporterzy, którzy w trakcie wyprawy kierują się pasją poznawczą i - co równie ważne - chęcią zarobienia pieniędzy. Nie podróżują sami. Narratorowi książki Szczerka towarzyszy Hawran, pełniący - zdaniem autora - niezwykle ważną funkcję: „Tak, Hawran już kiedyś był na Ukrainie. I z tego powodu robił teraz za mędrca-przewodnika" ${ }^{49}$. Bohater książki Thompsona podróżuje z kolei w towarzystwie doktora Gonzo, który przedstawiony zostaje jako adwokat dziennikarza, lecz szybko okazuje się, że zakres jego obowiązków zdecydowanie wykracza poza kwestie prawne. Jego zadaniem staje się chociażby zorganizowanie samochodu czy zdobycie narkotyków.

Swą opowieść rozpoczyna Szczerek od rozdziału zatytułowanego $O j a$, w którym narrator już w pierwszym akapicie zostaje przedstawiony jako Łukasz Ponczyński. Tak sugestywne, otwierające książkę wyeksponowanie osoby

47 Tamże, s. 41.

48 Por. W. Tochman, Wściekty pies [w:] tegoż, Wściekty pies, Kraków 2007, s. 117-138.

49 Z. Szczerek, dz. cyt., s. 10. 
mówiącej może być odczytywane jako próba zwrócenia uwagi odbiorcy na nietypową kreację narratora, będącą jednym z najistotniejszych elementów dziennikarstwa gonzo. Adamczewska zauważa ${ }^{50}$, że w przypadku tego rodzaju twórczości sposób ukształtowania podmiotu tekstowego spełnia określone kryteria charakterystyczne dla „ja” sylleptycznego, choć niektóre z nich traktuje niejako à rebours ${ }^{51} . \mathrm{Z}$ jednej strony narrator tekstu wykazuje wiele cech wspólnych z autorem zewnętrznym, z drugiej jednak - niejako wbrew klasycznej teorii Ryszarda Nycza - autor i narrator podpisują się odmiennym imieniem i nazwiskiem. W Przyjdzie Mordor... Szczerek podaje nawet lakoniczne wyjaśnienie zastosowania takiego właśnie zabiegu w swych wcześniejszych tekstach:

Najlepsze stałe zlecenie dostałem z jednego ze świeżo powstałych w Krakowie portali internetowych. (...) Wcześniej jednak musiałem wymyślić sobie pseudonim. Nie chciałem publikować tych bzdur pod własnym nazwiskiem. Tak więc pisałem jako Paweł Poncki. Uznałem, że tak będzie cool. Biblijne pseudonimy zawsze dobrze brzmią

Dziennikarz konsekwentnie prowadzi grę z czytelnikiem, nie próbując w żaden wyszukany, quasi-naukowy sposób usprawiedliwiać i uzasadniać przyjętej strategii. Zastanawia przy tym fakt, iż tak silna autokrytyka formułowana jest właśnie na kartach reportażu utrzymanego w stylu gonzo, którego autor z jednej strony zaprasza czytelników do precyzyjnie wykreowanego świata, z drugiej - na ich oczach jednocześnie go dekonstruuje.

Przyjęta przez Szczerka strategia nawiązuje do kreacji narratora zastosowanej w Lęku i odrazie..., choć raczej twórczo ją reinterpretuje, aniżeli powiela. W książce Thompsona narrator przedstawiony zostaje jako Raoul Duke, który - zdaniem Jakuba Żulczyka - bez cienia wątpliwości postrzegany może być jako alter ego samego autora:

W Lęku i odrazie w Las Vegas mamy do czynienia z fascynującym przypadkiem reportera, który próbując oddać jak najmniej przekłamany obraz zastanej rzeczywistości, dochodzi do wniosku, że najlepszym bohaterem, jak i symbolem opisywanych przemian społecznych będzie on sam ${ }^{53}$.

$\mathrm{Na}$ kartach książki dziennikarz wielokrotnie sygnalizuje odbiorcy możliwość odczytywania jej jako tekstu o walorach dokumentarnych, który

${ }^{50}$ Por. I. Adamczewska, Wariacje..., dz. cyt., s. 194-195.

51 Tamże.

52 Z. Szczerek, dz. cyt., s. 99.

${ }^{3}$ J. Żulczyk, W poszukiwaniu „amerykańskiego snu”. Postowie [w:] H.S. Thompson, dz. cyt., s. 258. 
traktowany być powinien nie tyle jako zakorzeniona w fikcji i autorskiej wyobraźni opowieść, ile raczej jako zapis autentycznych wydarzeń. O istniejących, choć niedoprecyzowanych bliżej koligacjach między autorem a narratorem odbiorca dowiaduje się z rozmowy dziennikarza z recepcjonistą, zjawiającym się w pokoju gościa z nietypową wiadomością:

Recepcjonista nadal się uśmiechał.

- Właśnie przyszedł do pana telegram. A właściwie nie do pana, tylko do kogoś o nazwisku Thompson, ale napisane jest: „Do rąk własnych Raoula Duke’a”. Wie pan, o co chodzi?

(...)

Potaknąłem, nie mogąc wydobyć głosu.

- Tak - wykrztusiłem wreszcie. - Wszystko wiem ${ }^{54}$.

Zaadresowana do Thompsona-Duke’a wiadomość jest - jak się wydaje próbą zwrócenia uwagi czytelnika na skomplikowany status podmiotu mówiącego, który z jednej strony ma charakter tekstowy i przynależy do przestrzeni dzieła, z drugiej zaś chce być postrzegany jako autentyczny, a nawet - co więcej - pod wieloma względami tożsamy z autorem zewnętrznym.

\section{Podsumowanie}

Nakreślona w niniejszym szkicu analiza komparatystycza tekstów Thompsona i Szczerka wykazała istnienie rozmaitych wielopoziomowych zależności pomiędzy obiema pracami. Dostrzegalne są one zarówno w stylu prowadzonej narracji, obfitującej w wulgaryzmy i zbliżonej momentami do języka potocznego, jak i w poruszanej przez autorów tematyce. Obaj twórcy w swych tekstach konsekwentnie zrywają z tradycyjnym dziennikarstwem opartym na zasadach rzetelności i obiektywizmu. Zarówno Ameryka Thompsona, jak i Ukraina Szczerka są przedstawiane w sposób subiektywny, zgodny - co deklarują sami piszący - z wymaganiami stawianymi reporterom przez współczesnych odbiorców mediów, jak również niektóre redakcje.

Reportaże utrzymane w stylu gonzo w swym sposobie mówienia o rzeczywistości naśladują strategie narracyjne zaczerpnięte z powieści sensacyjnych czy powieści drogi, choć też wielokrotnie otwarcie dyskutują z ich założeniami. Przyjdzie Mordor... oraz Lęk i odraza... to książki bogate w liczne autokomentarze dające się czytać jako opowieść o ludziach i wydarzeniach, a także o samym procesie tworzenia, konstruowania tekstów dziennikarskich w momencie, gdy zakwestionowaniu uległy już wszelkie zasady reporterskiego obiektywizmu. Szczerek i Thompson zdradzają czytelnikowi kulisy

54 H.S. Thompson, dz. cyt., s. 98-99. 
funkcjonowania mediów, przyznając się do kreowania przekazu atrakcyjnego z punktu widzenia odbiorcy. O ile jednak książka Thompsona miała na celu wywołanie rzeczywistej polemiki z propagowaną przez środki masowego przekazu wizją , amerykańskiego snu”, o tyle praca Szczerka wydaje się pozbawiona tego rodzaju ambicji. Jest raczej - jak się zdaje - próbą spojrzenia $\mathrm{z}$ dystansu również na samo gonzo jako na formę mającą przyciagnąć uwagę współczesnego czytelnika.

Nadmierna estetyzacja komunikatów medialnych, sprowadzająca się do opowiadania o wydarzeniach codziennych w sposób podniosły, a nierzadko też inspirowany rozmaitymi konwencjami literackimi czy filmowymi, obnaża główne słabości współczesnego dziennikarstwa, ale i - paradoksalnie - wyznacza dalszą drogę jego rozwoju. Infotainment ${ }^{55}$, epatowanie obrazami przemocy i śmierci oraz zakładanie, że każda opowiadana przez dziennikarza historia powinna przypominać tekst literacki z mocną ekspozycją, dynamicznym rozwinięciem i zaskakującą kulminacją, prowadzą do niebezpiecznego zacierania się granicy między reportażem a literaturą. Jednak rozwój gonzo uświadamia, że autentyczność i siła tekstu dziennikarskiego tkwi dziś przede wszystkim w osobistym doświadczeniu, którym dzieli się piszący ze swoimi czytelnikami. Forma ta, obszernie i dogłębnie analizująca określone zjawisko, staje się zatem odpowiedzią na szum informacyjny, a jednocześnie pytaniem o kierunek rozwoju reportażu w najbliższym czasie.

\section{Bibliografia}

Adamczewska I., Gonzo journalism, „Zagadnienia Rodzajów Literackich” 2014, z. 1. Adamczewska I., Wariacje na temat pewnego paktu. O dziennikarstwie gonzo, „Łódzkie Studia Literaturoznawcze" 2014, nr 3 (1).

Bauer Z., Dziennikarstwo "gonzo": epizod czy trwaty trend $w$ dziennikarstwie? [w:] Dziennikarstwo a literatura w XX i XXI wieku, red. K. Wolny-Zmorzyński, W. Furman, J. Snopek, Warszawa 2011.

Bielik-Robson A., Inna nowoczesność. Pytania o wspótczesna formutę duchowości, Kraków 2000.

Boynton R., The New New Journalism: Conversations with Americas Best Nonfiction Writers on Their Craft, New York 2005.

Drozdowicz J., Lęk i odraza. O popkulturowej obecności Huntera S. Thompsona [w:] Kultura popularna w spoteczeństwie wspótczesnym. Teoria i rzeczywistość, red. J. Drozdowicz, M. Bernasiewicz, Kraków 2010.

Featherstone M., Postmodernizm i estetyzacja życia codziennego, tłum. P. Czapliński, J. Lang [w:] Postmodernizm: antologia przektadów, red. R. Nycz, Kraków 1998.

55 Pojęcie powstałe z połączenia dwóch leksemów: information (informacja) oraz entertainment (rozrywka). 
Franklin B., Gonzo Journalism [w:] Key Concepts in Journalism Studies, red. B. Franklin, M. Hamer, M. Hanna, Trowbridge, Wiltshire 2005.

Frukacz K., Amerykańskie Nowe Dziennikarstwo po polsku? Transfer poetyk, problemy adaptacyjne, „Biblioteka Postscriptum Polonistycznego” 2015, nr 5.

Gorner P., Tom Wolfe: in Big League as a Writer [w:] Conversations with Tom Wolfe, red. D. McInnis Scura, Mississippi 1990.

Hartsock J.C., A History of American Literary Journalism: The Emergence of a Modern Narrative Form, Massachusetts 2000.

Kapuściński R., Lapidaria IV-VI, Warszawa 2008.

Kapuściński R., Nowe dziennikarstwo, „Akcent” 2012, nr 3.

Kąkolewski K., Wańkowicz krzepi, Lublin 1984.

Keeler J.D., Brown W., Tarpley D., Ethics [w:] American Journalism: History, Principles, Practices, red. W.D. Sloan, L. Mullikin Parcell, Jefferson, North Carolina-London 2002.

Nowacka B., Magiczne dziennikarstwo. Ryszard Kapuścinski w oczach krytyków, Katowice 2004.

Puto K., Małecka A., Bińczycki J., Wstęp, „Ha!art” 2013, nr 1 (41).

Swigger J., New Journalism [w:] Culture Wars: An Encyclopedia of Issues, Viewpoints, and Voices, red. R. Chapman, Armonk, NY 2010.

Szczerek Z., Przyjdzie Mordor i nas zje, czyli tajna historia Stowian, Kraków 2013.

The Reporter as Artist: A Look at the New Journalism Controversy, red. R. Weber, New York 1974.

Thompson H.S., Lęk i odraza w Las Vegas, tłum. M. Wróbel, M. Potulny, b.m. 2013.

Tochman W., Wściekty pies, Kraków 2007.

Welsch W., Estetyka i anestetyka, tłum. M. Łukasiewicz [w:] Postmodernizm. Antologia przektadów, red. R. Nycz, Kraków 1998.

Welsch W., Procesy estetyzacji. Zjawiska, rozróżnienia, perspektywy, tłum. J. Gilewicz [w:] Sztuka i estetyzacja, red. K. Zamiara, M. Golka, Poznań 1999.

Wolny-Zmorzyński K., Reportaż - jak go napisać, Warszawa 2004.

Wolny-Zmorzyński K., Kaliszewski A., Furman W., Gatunki dziennikarskie. Teoria, praktyka, język, Warszawa 2006.

Zelizer B., Allan S., Keywords in News and Journalism Studies, Glasgow 2010.

Zimnoch M., Reportaż w ptynnej nowoczesności, „Znak” 2012, nr 3. 